\title{
RENCANA PROGRAM DAN KEGIATAN PEMBELAJARAN SEMESTER (RPKPS)
}

\section{A. Identitas Mata Kuliah}
1. Nama Matakuliah
:Perbankan Syariah
2. Kode/SKS
:MPB463 / 2 SKS
3. Semester
: Wajib Semester Genap (IV)
4, Dosen Pembina
: Sunreni, SE, MM

\section{B. Kompetensi}

\section{Kompetensi Umum}

Setelah mengikuti perkuliahan ini diharapkan mahasiswa mampu menjadi individu dan makhluk sosial yang memiliki pengetahuan serta keyakinan untuk bersikap serta bijaksana dalam menghadapi perubahan persaingan dalam mencapai kemandirian keuangan yang islami.

\section{Kompetensi Khusus}

Setelah mengikuti mata kuliah ini mahasiswa diharapkan dibekali (kompetensi hardskill):
a. Mengidentifikasi perlunya mata kuliah Perbankan Syariah sebagai solusi keungan yang syar'i
b. Memahami manusia sebagai makhluk Tuhan yang saling membutuhkan antara satu dan lainnya
c. Memahami bahwa selalu terjadi perubahan dalam dunia keuangan, dan kita sebagai makhluk Tuhan harus tunduk pada hukum yang telah ditetapkan-NYA
d. Memahami fungsi, hukum, nilai, dan moral dalam upaya mendapatkan keadilan dan pemerataan kesejahteraan.
e. Memahami makna tentang kemajuan teknologi, pengetahuan dan kebudayaan yang memiliki efek terhadap kualitas hidup manusia dan kelembagaan.

Setelah mengikuti mata kuliah ini mahasiswa diharapkan dibekali (kompetensi softskill)
a. Mengaktualisasikan nilai-nilai syar'i dalam bisnis dan kehidupan
b. Meyakini bahwa manusia sebagai makhluk yang memiliki potensi dan kemampuan untuk berkembang
c. Menyikapi perubahan Perbankan terutama bank syariah dan dinamika perubahan di dunia
d. Mampu beradaptasi dengan perubahan teknologi, pengetahuan dan budaya

\section{Jumlah jam:}

Kegiatan di dalam kelas ( 2 SKS x 45 menit x 14 minggu ):
a. Kuliah\& diskusi (Tatap Muka)
$=21 \mathrm{jam}(14$ pertemuan $)$
b, Ujian Tengah Semester
$=1,5 \mathrm{jam}$
c. Ujian Akhir Semester
$=1,5 \mathrm{jam}$
Jumlah
$=24 \mathrm{jam}$ 


\section{Jadwal Perkuliahan}

\begin{tabular}{|c|c|c|c|c|c|}
\hline \multirow[t]{2}{*}{$\mathrm{Mg}$} & \multicolumn{2}{|c|}{ Kemampuan Akhir } & \multirow[t]{2}{*}{ MATERI } & \multirow{2}{*}{$\begin{array}{c}\text { MODEL } \\
\text { PEMBELAJARAN }\end{array}$} & \multirow[t]{2}{*}{ PENUGASAN } \\
\hline & Hard Skill & Soft Skill & & & \\
\hline 1 & $\begin{array}{l}\text { 1. Mahasiswa mengetahui } \\
\text { tentang materi-materi yang } \\
\text { akan dipelajari selama satu } \\
\text { semester } \\
\text { 2. Perlunya mempelajari mata } \\
\text { kuliah perbankan syariah }\end{array}$ & $\begin{array}{ll}\text { 1. } & \text { Rasa memiliki } \\
\text { 2. } & \text { Pemahaman } \\
& \text { terhadap RPKPS }\end{array}$ & $\begin{array}{l}\text { 1. Penyampai } \\
\text { an RPKPS } \\
\text { 2. Kegunaan } \\
\text { 3. mata } \\
\text { kuliah } \\
\text { Perbankan } \\
\text { Syariah }\end{array}$ & $\begin{array}{ll}- & \text { Ceramah } \\
- & \text { Tanya } \\
& \text { Jawab }\end{array}$ & - $\quad$ Resume Individu \\
\hline 2 & 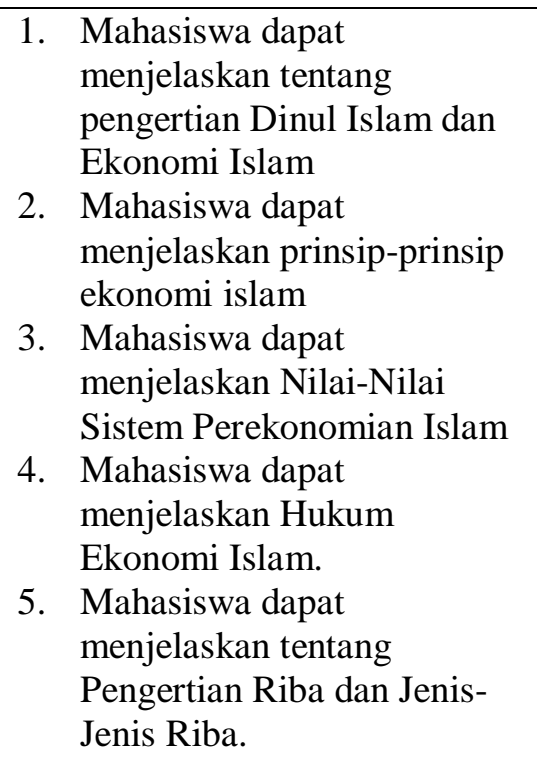 & $\begin{array}{ll}\text { 1. } & \text { Taat syari } \\
\text { 2. } & \text { Taat prosedur } \\
\text { 3. } & \text { Kebanggaan }\end{array}$ & $\begin{array}{l}\text { Dinul Islam dan } \\
\text { Ekonomi Islam }\end{array}$ & $\begin{array}{ll}\text { - } & \text { Ceramah } \\
\text { - } & \text { Tanya } \\
& \text { Jawab }\end{array}$ & - $\quad$ Resume Individ \\
\hline 3 & 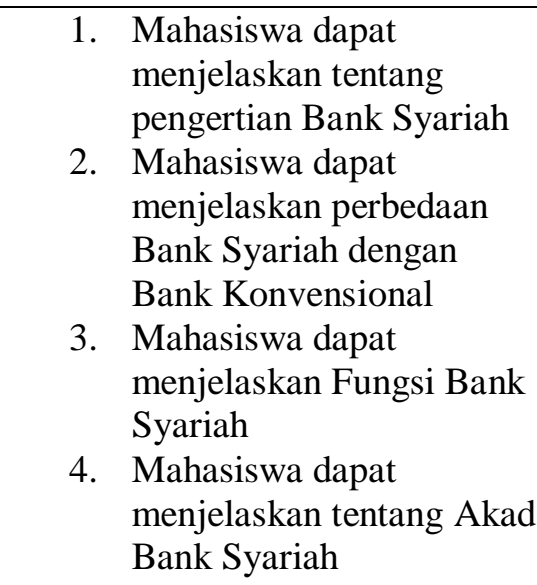 & $\begin{array}{l}\text { 1. taat prosedur } \\
\text { 2. Rasa memiliki }\end{array}$ & $\begin{array}{l}\text { Konsep Dasar } \\
\text { Perbankan Syariah }\end{array}$ & $\begin{array}{ll}\text { - } & \text { Ceramah } \\
\text { - } & \text { Tanya } \\
& \text { Jawab }\end{array}$ & - $\quad$ Resume Individ \\
\hline $4-5$ & $\begin{array}{l}\text { 1. Mahasiswa dapat } \\
\text { menjelaskan tentang } \\
\text { pelaksanaan prinsip syariah } \\
\text { dalam kegiatan } \\
\text { Penghimpunan Dana } \\
\text { 2. Mahasiswa dapat } \\
\text { menjelaskan tentang }\end{array}$ & $\begin{array}{ll}\text { 1. } & \text { Pemahaman } \\
\text { sistem } \\
\text { 2. Rasa memiliki } \\
\text { 3. Kebanggaan }\end{array}$ & $\begin{array}{l}\text { Kegiatan } \\
\text { Perbankan Syariah }\end{array}$ & $\begin{array}{ll}- & \text { Ceramah } \\
\text { - } & \text { Tanya } \\
& \text { Jawab }\end{array}$ & - $\quad$ Resume Individ \\
\hline
\end{tabular}




\begin{tabular}{|c|c|c|c|c|c|}
\hline & $\begin{array}{l}\text { pelaksanaan prinsip syariah } \\
\text { dalam kegiatan Penyaluran } \\
\text { Dana } \\
\text { 3. Mahasiswa dapat } \\
\text { menjelaskan tentang } \\
\text { pelaksanaan prinsip syariah } \\
\text { dalam kegiatan Pelayanan } \\
\text { Jasa }\end{array}$ & & & & \\
\hline 6 & $\begin{array}{l}\text { 1. Mahasiswa dapat } \\
\text { menjelaskan tentang Giro } \\
\text { dan Tabungan Wadiah } \\
\text { 2. Mahasiswa dapat } \\
\text { menjelaskan tentang } \\
\text { Tabungan dan Tabungan } \\
\text { Berjangka Mudharabah }\end{array}$ & $\begin{array}{l}\text { 1. taat prosedur } \\
\text { 2. rasa saling } \\
\text { memiliki }\end{array}$ & $\begin{array}{l}\text { Penghimpunan } \\
\text { Dana }\end{array}$ & $\begin{array}{ll}- & \text { Ceramah } \\
\text { - } & \text { Tanya } \\
& \text { Jawab }\end{array}$ & Resume individ \\
\hline 7 & 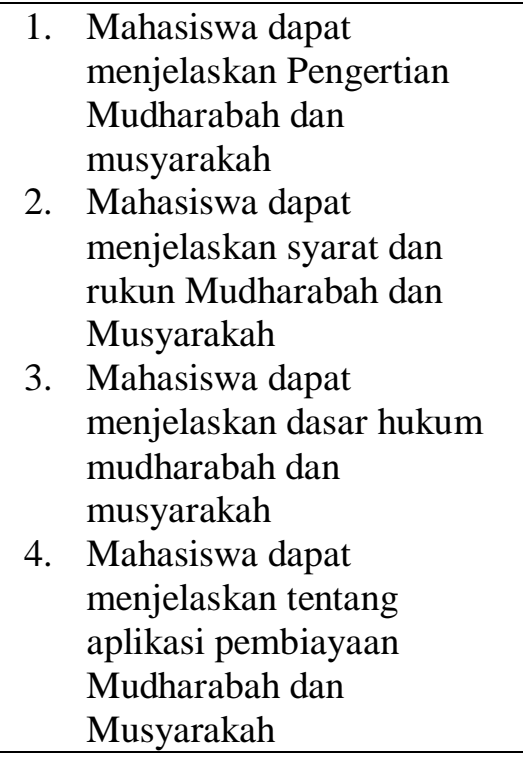 & $\begin{array}{l}\text { 1. Memahami } \\
\text { konteks } \\
\text { kerjasama } \\
\text { secara islami }\end{array}$ & $\begin{array}{l}\text { Pembiayaan } \\
\text { dengan prinsip } \\
\text { bagi hasil } \\
\text { (Mudharabah dan } \\
\text { Musyarakah) }\end{array}$ & $\begin{array}{ll}\text { - } & \text { Ceramah } \\
\text { - } & \text { Tanya } \\
& \text { Jawab }\end{array}$ & - $\quad$ Resume Individ \\
\hline 8 & & \multicolumn{4}{|c|}{ UTS } \\
\hline 9 & 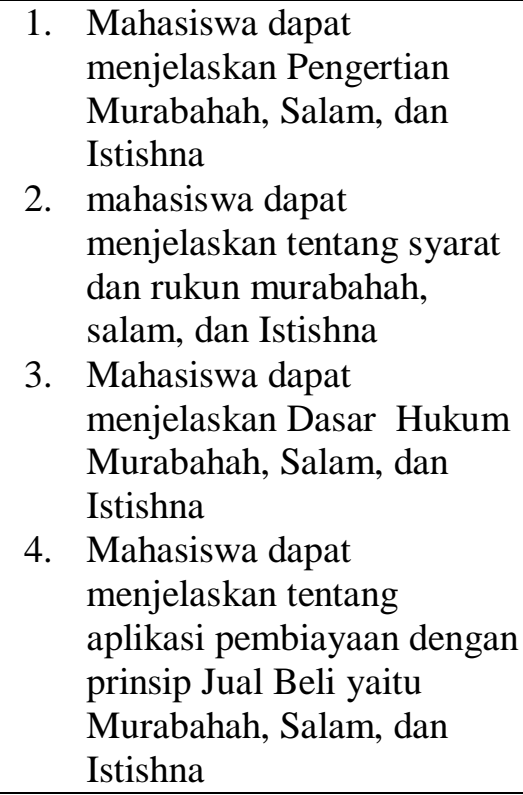 & 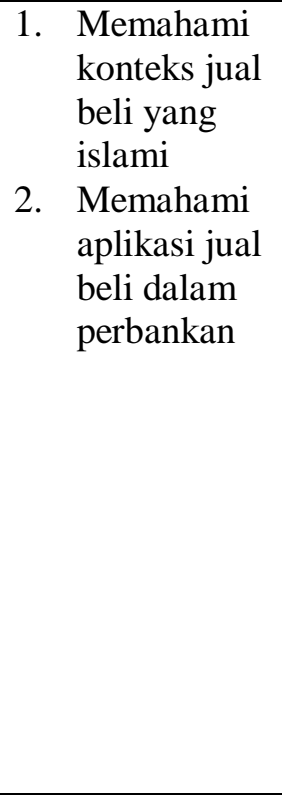 & $\begin{array}{l}\text { Pembiayaan } \\
\text { dengan Prinsip } \\
\text { Jual Beli } \\
\text { (Murabahah, } \\
\text { Salam, dan } \\
\text { Istishna) }\end{array}$ & $\begin{array}{ll}\text { - } & \text { Ceramah } \\
\text { - } & \text { Tanya } \\
& \text { Jawab }\end{array}$ & $\begin{array}{ll}- & \text { Resume } \\
& \text { Kelompok }\end{array}$ \\
\hline 10 & 1. Mahasiswa dapat & 1. Memahami & Pembiayaan & - Ceramah & Resume \\
\hline
\end{tabular}




\begin{tabular}{|c|c|c|c|c|c|c|}
\hline & $\begin{array}{l}\text { menjelaskan Pengertian } \\
\text { Ijarah dan Ijarah Muntahiya } \\
\text { bittamlik } \\
\text { 2. Mahasiswa dapat } \\
\text { menjelaskan syarat dan } \\
\text { rukun ijarah dan ijarah } \\
\text { muntahiya bittamlik } \\
\text { 3. Mahasiswa dapat } \\
\text { menjelaskan Dasar Hukum } \\
\text { Ijarah dan Ijarah Muntahiya } \\
\text { Bittamlik } \\
\text { 4. Mahasiswa dapat } \\
\text { menjelaskan Kegiatan } \\
\text { pembiayaan dengan prinsip } \\
\text { Sewa yaitu Ijarah dan Ijarah } \\
\text { Muntahiya Bittamlik }\end{array}$ & $\begin{array}{l}\text { konteks } \\
\text { bermuamalat } \\
\text { dengan sistem } \\
\text { sewa dan } \\
\text { pesanan } \\
\text { produksi } \\
\text { 2. Mampu } \\
\text { mengaplikasik } \\
\text { an hukum } \\
\text { syari dalam } \\
\text { berbisnis }\end{array}$ & $\begin{array}{l}\text { dengan Prinsip } \\
\text { Sewa ( Ijarah dan } \\
\text { Ijarah Muntahiya } \\
\text { bittamlik) }\end{array}$ & $\begin{array}{ll}\text { - } & \text { Tanya } \\
& \text { Jawab }\end{array}$ & & Kelompok \\
\hline 11 & 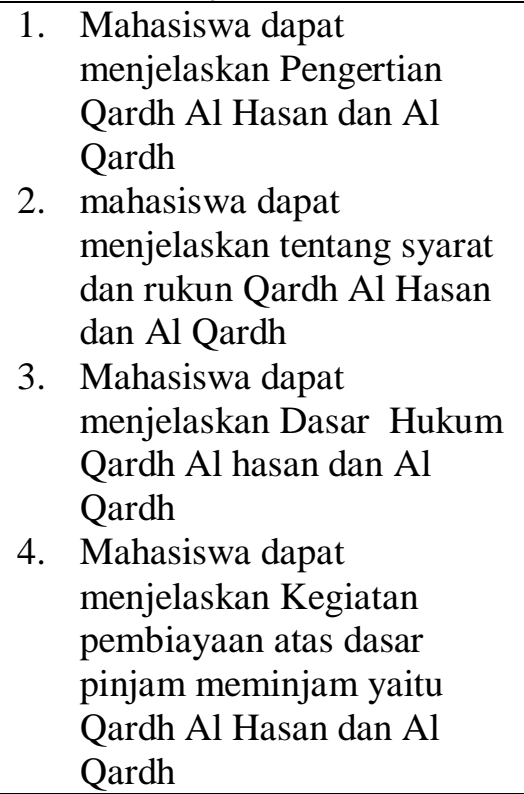 & $\begin{array}{ll}\text { 1. } & \text { Memahami } \\
\text { pelaksanaan } \\
\text { pinjam } \\
\text { meminjam } \\
\text { dan gadai } \\
\text { dalam islam } \\
\text { 2. } \\
\text { Mampu } \\
\text { melaksanakan } \\
\text { aplikasinya }\end{array}$ & $\begin{array}{l}\text { Pembiayaan atas } \\
\text { dasar pinjam } \\
\text { meminjam (Qardh) }\end{array}$ & $\begin{array}{ll}\text { - } & \text { Ceramah } \\
\text { - } & \text { Tanya } \\
& \text { Jawab }\end{array}$ & - & $\begin{array}{l}\text { Resume } \\
\text { Kelompok }\end{array}$ \\
\hline $12-13$ & $\begin{array}{l}\text { 1. } \begin{array}{l}\text { Mahasiswa dapat } \\
\text { menjelaskan Pengertian } \\
\text { produk jasa perbankan } \\
\text { syariah. }\end{array} \\
\text { 2. } \begin{array}{l}\text { mahasiswa dapat } \\
\text { menjelaskan tentang syarat } \\
\text { dan rukun masing-masing } \\
\text { produk jasa perbankan }\end{array} \\
\text { syariah } \\
\text { 3. Mahasiswa dapat } \\
\text { menjelaskan Dasar Hukum } \\
\text { produk jasa perbankan } \\
\text { syari'ah } \\
\text { 4. Mahasiswa dapat } \\
\text { menjelaskan aplikasi Produk } \\
\text { Jasa Perbankan Syariah }\end{array}$ & $\begin{array}{ll}\text { 1. } & \text { Memahami } \\
\text { usul produk } \\
\text { jasa syariah } \\
\text { 2. } \\
\text { Mampu } \\
\text { mengaplikasik } \\
\text { annya dalam } \\
\text { kehidupan }\end{array}$ & $\begin{array}{l}\text { Produk Jasa } \\
\text { Perbankan } \\
\text { Syari'ah }\end{array}$ & $\begin{array}{ll}\text { - } & \text { Ceramah } \\
\text { - } & \text { Tanya } \\
& \text { Jawab }\end{array}$ & - & $\begin{array}{l}\text { Resume } \\
\text { Kelompok }\end{array}$ \\
\hline
\end{tabular}




\begin{tabular}{|c|c|c|c|c|c|}
\hline 14 & $\begin{array}{l}\text { 1. Mahasiswa dapat } \\
\text { menjelaskan kasus tentang } \\
\text { Peran serta Perbankan } \\
\text { Syariáh dalam Dunia Usaha } \\
\text { 2. Mahasiswa dapat } \\
\text { menjelaskan Harapan } \\
\text { masyarakat terhadap } \\
\text { Perbankan Syariah dalam } \\
\text { meningkatkan kesejahteraan }\end{array}$ & $\begin{array}{ll}\text { 1. } & \text { Kepedulian } \\
\text { 2. } & \text { Solidaritas } \\
\text { 3. } & \text { Inovatif }\end{array}$ & Pembahasan kasus & $\begin{array}{ll}\text { - } & \text { Ceramah } \\
\text { - } & \text { Tanya } \\
& \text { Jawab }\end{array}$ & $\begin{array}{ll}- & \text { Resume } \\
& \text { Kelompok }\end{array}$ \\
\hline 15 & $\begin{array}{l}\text { 1. Mahasiswa dapat } \\
\text { menjelaskan permasalahan } \\
\text { yang biasanya terjadi pada } \\
\text { perbankan syariah dan } \\
\text { mencari solusi dari } \\
\text { permasalahan tersebut. }\end{array}$ & $\begin{array}{ll}\text { 2. } & \text { Kerjasama } \\
\text { 3. } & \text { Inovatif }\end{array}$ & $\begin{array}{l}\text { Pembahasan Kasus } \\
\text { tentang Kegiatan } \\
\text { Perbankan Syariah }\end{array}$ & - $\quad$ Presentasi & $\begin{array}{ll}- & \text { Resume } \\
& \text { Kelompok }\end{array}$ \\
\hline
\end{tabular}

\section{E. Materi Perkuliahan}

Materi perkuliahan yang dibahas, tersusun dalam bentuk topik sebagai berikut :

\begin{tabular}{|c|c|c|}
\hline TOPIK & MATERI & RINCIAN ISI MATERI \\
\hline 1 & Dinul Islam dan Ekonomi Islam & $\begin{array}{l}\text { 1. Pengertian Dinul Islam dan Ekonomi Islam. } \\
\text { 2. Prinsip-Prinsip Ekonomi Islam } \\
\text { 3. Nilai-Nilai Sistem Perekonomian Islam } \\
\text { 4. Hukum Ekonomi Islam } \\
\text { 5. Pengertian Riba dan Jenis-Jenis Riba } \\
\end{array}$ \\
\hline 2 & Konsep Dasar Perbankan Syariah & $\begin{array}{l}\text { 1. Pengertian Bank Syariah } \\
\text { 2. Perbedaan Bank Syariah dan Bank Konvensional } \\
\text { 3. Fungsi Bank Syariah } \\
\text { 4. } \text { Akad Bank Syariah }\end{array}$ \\
\hline 3 & Kegiatan Perbankan Syariah & $\begin{array}{l}\text { 1. Pelakasanaan Prinsip Syariah dalam Kegiatan Penghimpunan } \\
\text { Dana } \\
\text { 2. Pelakasanaan Prinsip Syariah dalam Kegiatan Penyaluran Dana } \\
\text { 3. Pelakasanaan Prinsip Syariah dalam Kegiatan Pelayanan Jasa }\end{array}$ \\
\hline 4 & Penghinmpunan Dana & $\begin{array}{l}\text { 1. Giro dan tabungan Wadiah } \\
\text { 2. Tabungan dan Tabungan Berjangka Mudharabah }\end{array}$ \\
\hline 5 & $\begin{array}{l}\text { Pembiayaan dengan Prinsip Bagi Hasil } \\
\text { (Mudharabah dan Musyarakah) }\end{array}$ & $\begin{array}{l}\text { 1. Pengertian Mudharabah dan Musyarakah } \\
\text { 2. Syarat dan rukun mudharabah dan musyarakah } \\
\text { 3. Dasar Hukum mudharabah dan musyarkaah } \\
\text { 4. Aplikasi Kegiatan pembiayaan mudharabah dan musyarakah }\end{array}$ \\
\hline 6 & $\begin{array}{l}\text { Pembiayaan dengan Prinsip Jual Beli } \\
\text { (Murabahah, salam dan Istishna) }\end{array}$ & $\begin{array}{l}\text { 1. Pengertian Murabahah, Salam, dan Istishna } \\
\text { 2. Rukun dan syarat murabahah, salam, dan istishna } \\
\text { 3. Dasar Hukum Murabahah, Salam, dan Istishna } \\
\text { 4. Aplikasi Kegiatan Pembiayaan Murabahah, Salam, dan Istishna }\end{array}$ \\
\hline 7 & $\begin{array}{l}\text { Pembiayaan dengan Prinsip Sewa ( } \\
\text { Ijarah dan Ijarah Muntahiya Bittamlik) }\end{array}$ & $\begin{array}{l}\text { 1. Pengertian Ijarah dan Ijarah Muntahiya Bittamlik } \\
\text { 2. Rukun dan syarat ijarah dan ijarah muntahiya bittamlik } \\
\text { 3. Dasar Hukum Ijarah dan Iijarah Muntahiya Bittamlik } \\
\text { 4. Aplikasi Kegiatan pembiayaan Ijarah dan Ijarah Muntahiya } \\
\text { Bittamlik }\end{array}$ \\
\hline 8 & $\begin{array}{l}\text { Pembiayaan atas dasar pinjam } \\
\text { meminjam (Qardh) }\end{array}$ & $\begin{array}{l}\text { 1. Pengertian Qardh Al Hasan dan Al Qardh } \\
\text { 2. Rukun dan Syarat Qardh Al Hasan dan Al Qardh } \\
\text { 3. Dasar Hukum Qardh Al Hasan dan Al Qardh } \\
\text { 4. Aplikasi Kegiatan Pembiayaan Qardh Al Hasan dan Al Qardh }\end{array}$ \\
\hline 9 & Produk Jasa Perbankan syari'ah & $\begin{array}{l}\text { 1. Pengertian produk jasa perbankan syariah. } \\
\text { 2. Rukun dan syarat produk jasa perbankan syariah }\end{array}$ \\
\hline
\end{tabular}




\begin{tabular}{|c|c|c|}
\hline & & $\begin{array}{l}\text { 3. Dasar Hukum produk jasa perbankan syari'ah } \\
\text { 4. Aplikasi Produk Jasa Perbankan Syari'ah }\end{array}$ \\
\hline 10 & Peran Perbankan Syariáh Dunia Usaha & $\begin{array}{l}\text { 1. Peran serta Perbankan syariáh dalam Dunia Usaha } \\
\text { 2. Harapan masyarakat terhadap Perbankan Syariah dalam } \\
\text { meningkatkan kesejahteraan }\end{array}$ \\
\hline 11 & $\begin{array}{l}\text { Kasus-Kasus Kegiatan Pebankan } \\
\text { Syariah }\end{array}$ & $\begin{array}{l}\text { 1. kegiatan penghimpunan Dana } \\
\text { 2. Kegiatan Penyaluran Dana } \\
\text { 3. Kegiatan Pelayanan Jasa }\end{array}$ \\
\hline
\end{tabular}

\section{F. Penilaian}

a. Penilaian meliputi :

1. Penilaian Kehadiran

$$
=15 \%
$$

2. Ujian Tengah Semester (UTS)

$$
=25 \%
$$

3. Ujian Akhir Semester (UAS)

$=30 \%$

4. Tugas presentasi

$=20 \%$

5. Partisipasi

$=10 \%$

\section{b. Syarat mengikuti ujian semester}

1. Kehadiran $75-100 \%$ : boleh mengikuti ujian

2. Kehadiran $<75 \%$ : tidak boleh mengikuti ujian

\begin{tabular}{|c|c|c|}
\hline A: & $>80$ & $=$ sangat baik \\
\hline B : & 66- 80 & $=$ baik \\
\hline $\mathrm{C}:$ & $56-65$ & $=$ cukup \\
\hline $\mathrm{D}:$ & $45-55$ & $=$ sedang \\
\hline $\mathrm{E}$ : & $<45$ & $=$ kurang \\
\hline
\end{tabular}

\section{c.Standar konversi nilai yang direncanakan:}

\section{G. Referensi}

Adiwarman Karim, 2010, Bank Islam: Analisis Fiqih danKeuangan, Jakarta: Raja Grafindo Persada.

Amir Macchmud, 2010, Bank Syari'ah: Teori, Kebijakan, dan Studi Empiris di Indonesia, Jakarta: Erlangga.

Antonio Syafi’i Muhammad, 2001, Bank Syariah dari Teori ke Praktik, Gema Insani, Jakarta

Ascarya, 2013, Akad dan Produk Bank Syariah, Edisi Pertama Cetakan ke empat, PT RajaGrafindo Persada, Jakarta

Cecep Maskanul Hakim, Modul Pelatihan Bank Syariah, Bank Indonesia

Iman Gzali, 2002, Benang Tipis antara Halal dan Haram, Putra Pelajar, Surabaya

Ismail, 2011, Perbankan Syariah, Edisi Pertama, Kencana Prenada Media Group, Jakarta

Kuncoro Mudrajad,2005 Manajemen Bank Syariah, Edisi Revisi, UPP AMP YKPN. Yogyakarta

Mohammad. 2004. Akuntansi untuk Zakat Profesi.

2005. Bank Syariah: Problem dan Prospek Perkembangan di Indonesia. Graha Ilmu.

Siregar, 2010, Perbankan Syariah, Pelatihan Perbankan Syariah, Galamedia, Bandung

Syafe'I, Antonio. 2000. Bank Syariah bagi para Bankir dan Praktisi.

Yusuf Qardawi, 2003, Halal Haram dalam Islam, Intermedia, Jakarta 1997, Norma dan Etika, Gema Insani Press, Jakarta 


\section{H. Perencanaan Monitoring dan Umpan Balik}

Rencana dokurnen monitoring dan umpan balik meliputi dan diwujudkan dalam bentuk form-formyang terdiri atas:

a. Rencana dokumen/form kegiatan mingguan,

b. Rencana dokumen/form urnpanbalik dari mahasiswa, dan

c. Rencana dokumen/form perubahan

Form kegiatan mingguan diisi oleh dosen yang berisi informasi tentang: waktu perkuliahan dimulaidan diakhiri, waktu kehadiran masing-masing mahasiswa, bentuk partisipasi mahasiswa, kendaladalam perkuliaahan.

\section{FORMAT KEGIATAN MINGGUAN}

\begin{tabular}{|l|c|c|c|c|c|c|}
\hline \multirow{2}{*}{$\begin{array}{c}\text { Nama, } \\
\text { Mahasiswa }\end{array}$} & \multicolumn{2}{|c|}{ Waktu kuliah } & \multicolumn{2}{c|}{$\begin{array}{c}\text { Waktu } \\
\text { Kehadiran/mahasiswa }\end{array}$} & \multirow{2}{*}{$\begin{array}{c}\text { Bentuk } \\
\text { Partisipasi } \\
\text { Mahasiswa }\end{array}$} & Keterangan \\
\cline { 2 - 5 } & mulai & akhir & Hadir & Jam & \\
\hline A & & & & & & \\
\hline B & & & & & & \\
\hline
\end{tabular}

\section{FORMAT UMPAN BALIK DARI MAHASISWA}

1. Apa yang anda dapatkan dalam. perkuliahan hari ini?

2. Apa kesulitan anda hari ini?

3. Apa yang anda, sukai dalam,kuliah hari ini?

4. Apa yang tidak anda sukai dalam kuliah hari ini?

Masalah yang bersifat umum. segera diperbaiki dan langsung diterapkan pada pertemuan berikutnya, sedangkan yang sifatnya mendasar akan dicatat untuk perbaikan pada semesterberikutnya.

Perencanaan Evaluasi adalah sebagai berikut:

\section{FORMAT PERUBAHAN}

\begin{tabular}{|c|c|c|}
\hline GAP & AKAR MASALAH & ALTERNATIF SOLUSI \\
\hline & & \\
\hline & & \\
\hline
\end{tabular}

\section{Evaluasi meliputi:}

a. Hasil pembelajaran

Evaluasi terhadap kemampuan mahasiswa dalam memahami konsep dilakukan secara tertulis sebanyak 2 kali, yaitu Ujian Tengah Semester (UTS) dan Ujian Akhir Semester (UAS) terjadwal. Hasil ini menggambarkan kemampuan individual mahasiswa dalam mencapai target kompetensi yang berhubungan dengan kemampuan pemahaman, terhadap materi perkuliahan yang diberikan. Dari sini dianalisis persentase mahasiswa yang berhasiI mencapai target kompetensi tersebut.

Evaluasi terhadap kemampuan praktis mahasiswa dilakukan pada setiap kali pembahasan materi yang berhubungan dengan praktek tersebut.

\section{b. Proses pembelajaran}


Proses pembelajaran dievaluasi dengan menganalisis monitoringform dan umpan balik seperti contoh di atas, untuk melihat keefektifan dari setiap komponen pembelajaran.

c. Hambatan dan kekurangan

Jumlah mahasiswa yang cukup besar, yang mencapai di atas 40 orang merupakan hambatan bagi dosen dalam memberikan feedback kepada mahasiswa secara individual. Dalam setiap minggu pemberian feedback akan dilakukan dengan membahas beberapa contoh tugas yang dikategorikan bagus, dan mahasiswa yang tugasnya bagus dijadikan sebagai tutor untuk beberapa temannya. Hasil tutor dilaporkan oleh mahasiswa yang bersangkutan kepada dosen dan akan dijadikan sebagai nilai tambah bagi tutor.

Keterlambatan mahasiswa mengisi KRS (selama ini banyak terjadi) juga menjadi penghambat pembelajaran. Oleh karena itu, peranan tutor di sini juga amat penting. Mereka diharuskan mempelajari materi yang tidak sempat mereka ikuti di kelas di rumah dan menanyakan kepada tutor hal-hal yang kurang mereka pahami, termasuk dalam pengerjaan tugas-tagas. Keberhasilan tutor sangat tergantung pada komunikasi tutor dengan dosen.

\section{d. Kemungkinan perbaikan}

Materi untuk contoh aplikasi dan materi lanjut dapat berubah sesuai dengan minat dan perkembangan mahasiswa. Setiap menemukan kendala dalam pembelajaran, dosen segera mencari akar masalah dan mencari solusi alternatif, yang selanjutnya pada pertemuan berikutnya, dilakukan perbaikan. Tetapi bila masalah itu tidak bisa dilaksanakan segera, maka direncanakan perbaikan pada semester berikutuya.

Mengetahui

Ketua Prodi Manajemen

Dr. Agussalim M., SE., MS
Padang, 27 April 2015

Dosen yang bersangkutan 